\title{
Stock Investment Decision: The Effects of Personal Factors and Moderating Role of Years of Service
}

\author{
TIPRI ROSE KARTIKA \\ Publishing Department \\ State Polytechnic of Creative Media \\ Jakarta, INDONESIA \\ NOPRIADI SAPUTRA \\ Management Department, Binus Business School, \\ Binus University, \\ Jakarta, INDONESIA \\ DAVID TJAHJANA \\ Universitas Multimedia Nusantara \\ Jakarta, INDONESIA \\ ADLER HAYMANS MANURUNG \\ Faculty of Business and Economics \\ Bhayangkara Jaya University \\ Jakarta, INDONESIA
}

\begin{abstract}
This paper aims to elaborate stock investment decision and to examine the impact of five influential factors as independent variables and the influence of years of investment as mediating variable. This paper is based on empirical study which involved 286 individual investors in Indonesia Stock Exchange using data from Riri et.al (2020). Structural equation modelling approach was used for estimating relationship between influential factors (e.g., personal financial needs, overconfidence, advocate recommendation, social relevance, and self or firm image) on stock investment decisions. The result found that decision on stock investment is determined by social relevance, overconfidence, personal financial need, and advocate recommendation significantly and positively. Years of Investment has played moderating role on relationship between for advocate recommendation and personal with stock investment decisions. Years of Investment is moderating variable to become a novelty this paper.
\end{abstract}

Key-Words: - stock investment decisions, years of investment, structural equation model

Received: June 18, 2021. Revised: November 29, 2021. Accepted: January 5, 2022. Published: January 7, 2022. .

\section{Introduction}

Investment in stock has high risk compared to other investment instrument. Investor should consider many things before, during, and after making decision in a stock investment in the market. The discussion on stock investment decision is a combination of psychology and finance theories which is called behaviour finance. Topic behaviour finance become a hot topic discussion in area of Finance Research. Some researcher investigated psychological aspect especially personal factor on stock investment decisions. Zahera and Bansal (2018) developed systematic literature review on individual behaviour to stock investment decisions. Wang (2001) have explored non-rational investors' survival in a game model with a large population. The study focused on sentiment and overconfidence of the investors Nagy and Obenberge (1994) investigated this case to individual equity investors with substantial holdings in Fortune 500 firm. Rizvi and Abrar (2015) and Ahmad (2017) studied 
affecting factors on individual investor behaviour in Pakistan. Phan and Zhou (2014a, 2014b) examined influential factors on individual investor behaviour in Vietnam. Chang (2010) and Riri and Manurung (2020) investigated the psychological factors which influences investment decision making in Indonesia.

Intention to buy stock in the market is sometimes called as stock investment decisions. Research in this area mostly related to psychology and finance. Selden (1912) introduced psychological aspect which is related in the stock market at the first time. Then, it was followed by Festinger (1957) who introduced theory of cognitive dissonance; Slovic (1972) who studied psychological of human judgment and its implications in investment decision making. Kahneman and Tversky (1979) introduced theory of prospect which is linked to analysis about decision making under risk. Daniel et.al (1998) have examined the relationship between psychology of investors and stock market over and. under reaction. Daniel et.al (2002) have examined the psychology of investor in policy implication and capital markets. Markowitz (1952) introduced portfolio theory that it explained behaviour of investor individual. They select high return and small risk for investment instrument. Boda and Sunitha (2018) have studied the psychology of investors in investment decision making which were focused on cognitive psychology and arbitrage limits. Pang and Zhou (2014) have proved that excessive optimism, overconfidence, psychology of risk, and herd behaviour on behavioural intention which mediated by attitude toward investment behaviour. Riri and Manurung (2020) stated that there are five personal factors (e.g., self or firm image, overconfidence, advocate recommendation, social relevance, and personal financial needs) have impacted on decisions of stock investment.

Previously empirical studies examined psychology factors directly impact on stock investment decisions. This paper addressed years of investment as moderating variable. Does year of investment strengthen or weaken the relationship five personal factors (e.g., firm or self-image, overconfidence, personal financial needs, social relevance, and advocate recommendation) on the decision of stocks investment? As moderating variable, years of investment could strengthen or weaken relationship between dependent and independent variables (Manurung, 2019, Sharma 1981). Moderating variable is a research contribution for stock investment decisions. This paper proposes a contribution by examining years of investment as moderating variable.

\section{Literature Review}

Stock investment decisions is about individual perspective on making decisions about how individual to decide buying or selling stocks in the market. At least, there are three conceptual theories: (1) utility theory, (2) personal intention, and (3) theory of planned behaviour (TPB). Utility theory is related on investment decision and explained how goods or services provide benefit to the individual by doing personal investment activities. Second, Selden (1912) had pioneered to establish the conceptual connection between psychology and stock market activities. Slovic (1972) studied psychological of human judgment and impacted on investment decision making. Kahneman and Tversky (1973) introduced a judgmental heuristic analysis on stock investment decision. Tversky and Kahneman (1979) introduced the theory of prospect to investment decision. This theory improved theory of utility, theory of cognitive dissonance advices that people have an inner drive to avoid dissonance or disharmony or to hold all related attitudes and behaviour in a dynamic harmony (Festinger, 1957). This is known as the principle of cognitive consistency

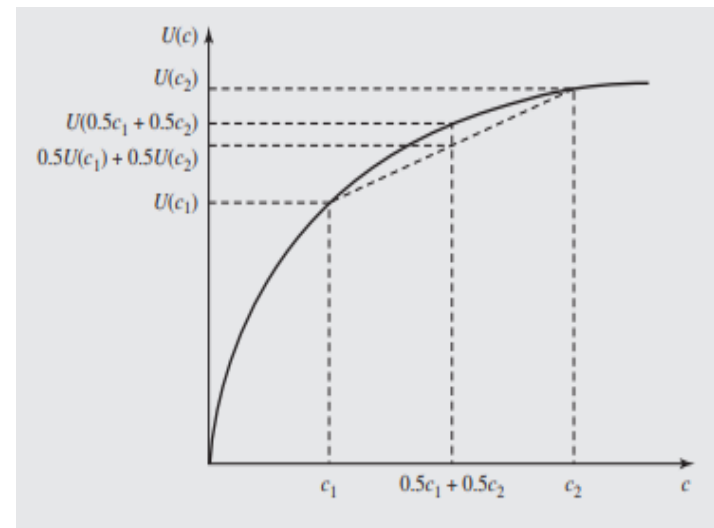

Figure 1. Utility for Personal

Source: Danthine and Donaldson (2015, p.5).

Third theory is theory of planned behaviour (TPB) which explains about individual intention for buying something. TPB was introduced by Ajzen (1991) which stated the intentions can be estimated with high accuracy from attitudes toward the perceived behavioural control, and subjective norms.

\section{Methods}

This paper is based on quantitative study which cross-sectional approach for examining the relationship between five individual factors as independent variables and year of investment as mediating variable with stock investment decision as dependent variable. Structural equation modelling 
was used for estimating effects of independent and mediating variables on dependent variable. The research used data which were provided by Riri et.al (2020). The respondent profile is demonstrated on Table 1 . The data was collected by utilizing online questionnaire from 385 individual stock investors in Indonesia Stock Exchange. The questionnaire consists of 29 indicators with Likert scale for measuring seven variables.

\section{Methodology}

Figure 2. shows the research model which consist of one moderating, one dependent, and five independent variables. The independent variables consist of personal financial needs, overconfidence, social relevance, self or firm image, and advocate recommendation. Stock investment decisions is a dependent variable and years of investment as moderating variable.

The mathematic model is as follows:

$$
\begin{aligned}
& \text { SIDi }=\text { a1 PFNi + a OVCi + a3 SRi + a4 SIMi } \\
& \text { + a5 AVRi + a6YOIi + a7(PNF*YOI)i } \\
& \text { + a8 (OVC*YOI)i + a9(SR*YOI)i } \\
& \text { + a10 (SIM*YOI)i + a11 (AVR*YOI)i }+\varepsilon
\end{aligned}
$$

$\mathrm{SID}=$ Stock Investment Decisions for $\mathrm{i}$

$\mathrm{PFN}=$ Personal Financial Needs for $\mathrm{i}$

$\mathrm{OVC}=$ overconfidence for $\mathrm{i}$

$\mathrm{SR}=$ Social Relevance for $\mathrm{i}$

SIM $=$ Self Image $/$ Firm Image for i

AVR $=$ Advocate Recommendation for $\mathrm{i}$

YOI $=$ Years of Investment.

In this discussion, research reported three finding which are validity and reliability instruments. It followed to discuss relationship independent variable to dependent variable. At the end, discussion of years of investment used as moderating variable in in this research.

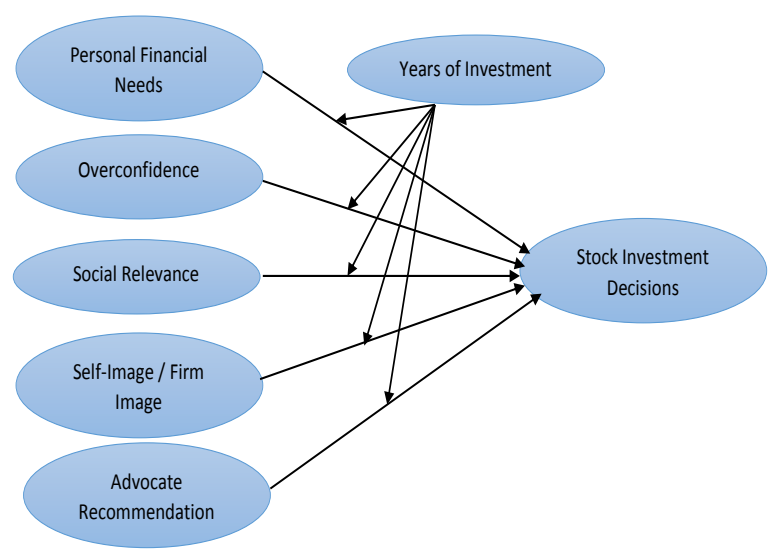

Figure 2. Research Model

\section{Hypothesis}

Someone needs more income to provide their life. Income is a variable of Personals Needs. Ali and Tariq (2013), Kabete and Kipkirong (2018) and Riri et al (2020) has proved their Hypothesis which is Personal Financial Needs affected Stock Investment Decision. Wang (2001), Zhou (2014), Xia et.al (2014), Tekc, , B., and N. Yllmaz and Riri et.al (2020) has done research for Overconfidence to affect Stock Investment Decision.

Ali and Tariq (2013) and Riri et.al (2020) has also proved their hypothesis about firm image affect stock Investment Decision.

Ali and Tariq (2013), Akbar et.al (2016) and Riri et al (2020) also proved the hypothesis of advocate recommendation affected stock investment decision.

\section{Result and Data Analysis}

Data is collected using a questioner which is processed by Smart PLS. The Result is shown by Table 1, Table 2. Table 3 and Table 4. Table 1 showed that Statistical Descriptive about profile the sample. Table 2 and 3 show the validity and Reliability test. This research used Questionnaire to get data for analysing of Stock Investment Decisions which are affected some variables. Loading Factor, AVE, communality, and composite reliability is used to test validity.

Value of AVE should be more than 0.5 that it explained variance of indicator. Chain (1998) stated that an indicator should have validity when it has loading factor equal and more than 0.7 and TStatistics more than 1.96. There are 27 indicators for 5 constructs. These indicators have Loading factor varying from 0.714 to 0.873 , and AVE also varying from 0.609 to 0.728 . It means that all indicator has validity to reflect constructs.

Then, this research also tested the reliability of indicators or instrument. CR (composite reliability) and CA (Cronbach's alpha) scores used to indicate reliability. CA score should be more than 0.7 and CR score should be also more than 0.7. CA scores are varying from 0.786 to 0.875 . CR scores of constructs are varying from 0.862 to 0.901 . The results indicate all constructs have reliability significantly. Based on the results, the instrument has validity and reliability, and it could be to do further exploration.

Table 4 shows the result of Hypothesis testing. Variable of Overconfidence, Advocate Recommendation, Social Relevance and Personal Needs significantly affected Stock Investment Decision. Firm Image does not affect Stock Investment Decision. Year of Investment as Moderating Variable could moderate Personal Needs 
and Advocate Recommendation to Stock Investment Decision.

\section{Discussion}

\begin{tabular}{|c|c|c|c|c|}
\hline \multicolumn{5}{|c|}{ Categories } \\
\hline \multirow{2}{*}{ Gender } & Male & 252 & $65.28 \%$ & $65.28 \%$ \\
\hline & Female & 134 & $34.72 \%$ & $100.00 \%$ \\
\hline \multirow{3}{*}{ Marital Status } & Single & 193 & $50.00 \%$ & $50.00 \%$ \\
\hline & Married & 175 & $45.34 \%$ & $95.34 \%$ \\
\hline & Divorced & 18 & $4.66 \%$ & $100.00 \%$ \\
\hline \multirow{4}{*}{ Age } & Less than 26-year-old & 92 & $23.83 \%$ & $23.83 \%$ \\
\hline & 26 - to 35-year-old & 187 & $48.45 \%$ & $72.28 \%$ \\
\hline & 36 - to 45 -year-old & 94 & $24.35 \%$ & $96.63 \%$ \\
\hline & More than 45-year-old & 13 & $3.37 \%$ & $100.00 \%$ \\
\hline \multirow{4}{*}{ Profession } & "Govemmental employee & 42 & $10.88 \%$ & $10.88 \%$ \\
\hline & Private sector employee & 123 & $31.87 \%$ & $42.75 \%$ \\
\hline & Entrepreneur & 118 & $30.57 \%$ & $73.32 \%$ \\
\hline & Other & 103 & $26.68 \%$ & $100.00 \%$ \\
\hline \multirow{4}{*}{ Education } & Senior high school & 39 & $10.10 \%$ & $10.10 \%$ \\
\hline & Vocational education & 37 & $9.59 \%$ & $19.69 \%$ \\
\hline & Bachelor's degree & 260 & $67.36 \%$ & $87.05 \%$ \\
\hline & Master's degree & 50 & $12.95 \%$ & $100.00 \%$ \\
\hline \multirow{4}{*}{ Years of Investment } & Less than 1 year & 78 & $20.21 \%$ & $20.21 \%$ \\
\hline & $1-3$ years & 136 & $35.23 \%$ & $55.44 \%$ \\
\hline & $4-5$ years & 106 & $27.46 \%$ & $82.90 \%$ \\
\hline & Less than 5 years & 66 & $17.10 \%$ & $100.00 \%$ \\
\hline
\end{tabular}

Table 1. Respondent Profile

In this sub-section, the discussion is how relationship overconfidence, self or firm image, advocate recommendation, personal needs, and social relevance toward decisions on stock investment. Riri et.al (2020) investigated determinant of stock investment decisions which are firm image or selfimage, overconfidence, social relevance, personal financial need, and advocate recommendation. The research model shows the results on Figure 2 and Figure 3.

Personal Need is a factor that someone to do for fulfil it. Income from salary does not enough to fulfil daily expenditure for his life, so she should do something to get another income by investment.

Personal need has relationship to stock investment decision which has weak relationship and significant of $10 \%$.
The coefficient path is 0.227 or less than relationship advocate recommendation with stock investment decision that it is small, and it called weak relationship. This personal need has the second highest effect to stock investment decision.

This research supports the previous research and the theory. Ali and Tariq (2013) investigated Personal Needs on Stock Investment Decisions. They found that strong influence Personal needs on individual equity investor decision making. Kabete and Kipkirong (2018) investigated personal need on stock investment decision. They found that personal financial needs had a positive effect on individual short-term investment decisions. Riri et.al (2020) examined effect of overconfidence on Stock Investment Decisions. They found that Personal Need significantly positive affect stock investment decisions. 
Sources: Process by Researcher

Table 2. The Analysis of Validity and Reliability

\begin{tabular}{|c|c|c|c|c|c|}
\hline VARIABLE & ITEMS & $\begin{array}{l}\text { OUTER } \\
\text { LOADING }\end{array}$ & AVE & CA & CR \\
\hline \multirow{4}{*}{ Overconfidence } & OC01 & 0.833 & \multirow{4}{*}{0.728} & \multirow{4}{*}{0.875} & \multirow{4}{*}{0.914} \\
\hline & $\mathrm{OCO} 2$ & 0.873 & & & \\
\hline & $\mathrm{OCO3}$ & 0.867 & & & \\
\hline & $\mathrm{OCO4}$ & 0.838 & & & \\
\hline \multirow{6}{*}{ Firm Image } & FI01 & 0.826 & \multirow{6}{*}{0.602} & \multirow{6}{*}{0.868} & \multirow{6}{*}{0.901} \\
\hline & FI02 & 0.744 & & & \\
\hline & Fi03 & 0.799 & & & \\
\hline & FI04 & 0.777 & & & \\
\hline & FI05 & 0.759 & & & \\
\hline & F106 & 0.799 & & & \\
\hline \multirow{4}{*}{ Social Relevance } & SR01 & 0.839 & \multirow{4}{*}{0.682} & \multirow{4}{*}{0.845} & \multirow{4}{*}{0.895} \\
\hline & SR02 & 0.848 & & & \\
\hline & SR03 & 0.8 & & & \\
\hline & SR04 & 0.815 & & & \\
\hline \multirow{4}{*}{ Advocate Recommendation } & AR01 & 0.816 & \multirow{4}{*}{0.657} & \multirow{4}{*}{0.826} & \multirow{4}{*}{0.884} \\
\hline & AR02 & 0.752 & & & \\
\hline & $\mathrm{AR} 03$ & 0.826 & & & \\
\hline & AR04 & 0.844 & & & \\
\hline \multirow{4}{*}{ Personal Need } & PN01 & 0.827 & \multirow{4}{*}{0.609} & \multirow{4}{*}{0.786} & \multirow{4}{*}{0.862} \\
\hline & PN02 & 0.783 & & & \\
\hline & PN03 & 0.794 & & & \\
\hline & PN04 & 0.714 & & & \\
\hline \multirow{5}{*}{ Stock Investment Decision } & SID01 & 0.761 & \multirow{5}{*}{0.613} & \multirow{5}{*}{0.842} & \multirow{5}{*}{0.888} \\
\hline & SID02 & 0.815 & & & \\
\hline & SID03 & 0.817 & & & \\
\hline & SID04 & 0.748 & & & \\
\hline & SID05 & 0.771 & & & \\
\hline
\end{tabular}

Sources: Process by Researcher

Table 3. Analysis of Discriminant Validity

\begin{tabular}{llcccccc}
\hline & Dimension & {$[\mathbf{1}]$} & {$[2]$} & {$[3]$} & {$[4]$} & [5] & [6] \\
\hline \hline$[1]$ & Adrocate Recommendation & $\mathbf{0 . 8 1 0}$ & & & & & \\
{$[2]$} & Firm Image & 0.764 & $\mathbf{0 . 7 7 6}$ & & & & \\
{$[3]$} & Overconfidence & 0.686 & 0.675 & $\mathbf{0 . 8 5 3}$ & & & \\
{$[4]$} & Personal Need & 0.827 & 0.634 & 0.633 & $\mathbf{0 . 7 8 1}$ & & \\
{$[5]$} & Stock Investment Decision & 0.780 & 0.733 & 0.683 & 0.733 & $\mathbf{0 . 7 8 3}$ & \\
{$[6]$} & Social Relevance & 0.730 & 0.852 & 0.625 & 0.654 & 0.721 & $\mathbf{0 . 8 2 6}$ \\
\hline \hline
\end{tabular}

Sources: Process by Researcher 
Advocate recommendation has relationship to stock investment decision which has weak relationship and significant of $1 \%$. The coefficient path is 0.263 or higher than relationship between Overconfidence and Stock Investment Decision, relationship firm image and stock investment decision a that is small, and it called weak relationship. These results supported previous
Social relevance has relationship to stock investment decision which has weak relationship and significant of $10 \%$. The coefficient path is 0.149 or higher than relationship firm image with stock investment decision that is small, and it called weak relationship. These results supported previous studies and theory. William (2007) investigated social relevance on stock investment decisions. They found

Table 4. Hypotheses Testing

\begin{tabular}{|c|c|c|c|c|c|}
\hline & Structural Model & $\begin{array}{c}\text { Path } \\
\text { Coefficien } \\
t \\
\end{array}$ & $\begin{array}{c}t- \\
\text { Statistic } \\
s \\
\end{array}$ & $\begin{array}{c}p- \\
\text { Value } \\
s \\
\end{array}$ & $\begin{array}{c}\text { Conclusio } \\
\mathbf{n}\end{array}$ \\
\hline $\mathrm{H} 1$ & Overconfidence $==>$ Stock Investment Decision & 0.186 & 4,041 & 0.000 & Accepted \\
\hline $\mathrm{H} 2$ & Firm Image ==> Stock Investment Decision & 0.127 & 1,955 & 0.051 & Rejected \\
\hline $\mathrm{H} 3$ & $\begin{array}{l}\text { Advocate Recommendation }==>\text { Stock Investment } \\
\text { Decision }\end{array}$ & 0.263 & 3,706 & 0.000 & Accepted \\
\hline $\mathrm{H} 4$ & Social Relevance $==>$ Stock Investment Decision & 0.149 & 2,485 & 0.013 & Accepted \\
\hline $\mathrm{H} 5$ & Personal Need ==> Stock Investment Decision & 0.227 & 4,081 & 0.000 & Accepted \\
\hline & Moderating Role & $\begin{array}{c}\text { Path } \\
\text { Coefficien } \\
t \\
\end{array}$ & $\begin{array}{c}t- \\
\text { Statistic } \\
s \\
\end{array}$ & $\begin{array}{c}p- \\
\text { Value } \\
s \\
\end{array}$ & $\begin{array}{c}\text { Conclusio } \\
\mathbf{n}\end{array}$ \\
\hline \multirow{5}{*}{$\begin{array}{c}\text { Years of } \\
\text { Investmen } \\
t\end{array}$} & Overconfidence $==>$ Stock Investment Decision & 0.052 & 1,233 & 0.218 & Rejected \\
\hline & Firm Image $==>$ Stock Investment Decision & -0.039 & 0.687 & 0.493 & Rejected \\
\hline & $\begin{array}{l}\text { Advocate Recommendation }==>\text { Stock Investment } \\
\text { Decision }\end{array}$ & -0.173 & 2,458 & 0.014 & Accepted \\
\hline & Social Relevance $==>$ Stock Investment Decision & -0.012 & 0.107 & 0.915 & Rejected \\
\hline & Personal Need $==>$ Stock Investment Decision & 0.170 & 2,524 & 0.012 & Accepted \\
\hline
\end{tabular}

Sources: Process by Researcher

studies and theory.

Ali and Tariq (2013) found advocate recommendation on Stock Investment Decisions. They found that strong influence advocate recommendation on individual equity investor decision making. Akbar et.al (2016) examined investor decision to buy shares that stated based on recommendation by stock brokerage, colleague in office, friend, and family.

Somathilake (2020) investigated advocate recommendation on stock investment decisions. He found that advocate recommendation influenced the individual investment decisions, but they do not much consider about accounting information. Riri et.al (2020) studied effect of advocate recommendation on Stock Investment Decisions. They found that advocate recommendation significantly positive affect stock investment decisions. that it strong influenced to invest in stocks. Riri et.al (2020) explored effect of Social Relevance on Stock Investment Decisions. They found that Social Relevance significantly positive affect Stock Decisions.

\section{Years of Investment}

In this research, year of investment was used to be moderating variable to estimate relationship Overconfidence, self-image / firm image, Social Relevance, Advocate Recommendation, Personal Financial Needs on stock investment decisions. Sharma (1991) and Manurung (2019) stated that moderating variable is a variable to strength or weak the relationship independent variable to dependent variable. This research found that Advocate Recommendation and Personal Financial Needs Variables are significantly to have relationship with stock investment decisions by year of investment as moderating variable. 


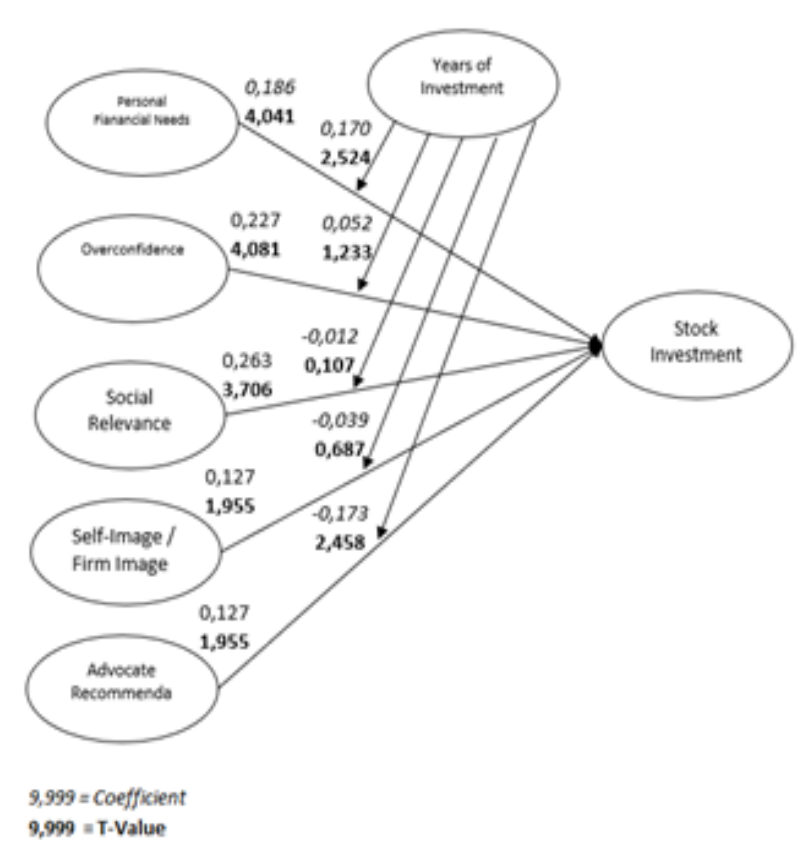

Figure 3. Statistical Output

\section{Conclusion}

This research has objective to investigate internal and external personal variable to affect stock investment decisions. This research is a research of behavior finance which is combined investment and psychology. Previous research mostly investigated directly factors affecting stock investment Decision without including moderating variable. This research entered year of investment as moderating variable. Based on result and previously explanation, this paper come to two conclusions: (1) all variable internal and external personal variable has effect to stock investment decisions by individual investor. (2) Year of investment could be a moderating variable for relationship between personal needs and advocate recommendation with stock investment decisions.

\section{References:}

[1] Akbar, M., Salman, A., Mughal, K. S., Fahad Mehmood, F. and N. Makarevic (2016), Factors Affecting the IndividualDecision Making: a Case Study of Islamabad Stock Exchange, European Journal of Economic Studies, , Vol. 15, Is.1, pp. 242-258.

[2] Ajzen, I. (1991). "The theory of planned behavior." Organizational Behavior and Human Decision Processes Vol. 50. No. 2, pp. 179-211.
[3] Ajzen, I. (2020), The theory of planned behavior: Frequently asked questions, Human Behavior \& Emerging Technology, Vol. 2, pp. 314-324. DOI: 10.1002/hbe2.195

[4] Baker, M and J. Wurgler (2007), Investor Sentiment in the Stock Market, Journal of Economic Perspectives, Vol. 21, No. 2, pp. $129-151$.

[5] Boda, J. R. and G. Sunitha (2018), Investor's Psychology in Investment Decision Making: A Behavioral Finance Approach, International Journal of Pure and Applied Mathematics, Vol. 119, No. 7, pp. 1253 1261.

[6] Chang, H. H. (2010), An Investigation of Psychological Factors Influencing Investment Decision Making, Indonesian Capital Market Review, Vol. 2, No. 2, pp 73 $-86$.

[7] Chin, W. W. (1998), Issues and Opinion on Structural Equation Modelling, MIS Quarterly, Vol. 22, No. 1, pp. vii-xvi

[8] Danthine, J. P. and J. B. Donaldson (2015), Intermediate Financial Theory, 3rd Eds., Academic Press of ELSEVIER.

[9] Daniel, K., Hirshleifer, D., \& Teoh, S. H. (2002). Investor psychology in capital markets: evidence and policy implications. Journal of Monetary Economics, 49(1), 139209. doi:10.1016/s0304-3932(01)00091-5

[10] Daniel, K., Hirshleifer, D., and A. Subrahmanyam (1998), Investor Psychology and Security Market Underand Overreactions, Journal of Finance, Vol. 53, No. 6, pp. 1839 - 1885.

[11] Dasgupta, R., \& Singh, R. (2018). Investor sentiment antecedents: A structural equation modeling approaching an emerging market context. Review of Behavioral Finance. doi:10.1108/rbf-072017-0068

[12] Deo, M. and V. Sundar (2015), Factors Influencing Investment Decisions of Individual Investors, Rajagiri Management Journal, Vol. 9, Issue 2, pp. 67 - 82.

[13] Festinger, L. (1957). A Theory of cognitive dissonance. Stanford, CA: Stanford University Press.

[14] Kabete, P. M. and D. T. Kipkirong (2018), Determinants of Individual Short-Term Investment Decisions: The Moderating Effect of Investors' Personal Quality in Nairobi Securities Exchange, American Based Research Journal, Vol. 7, Issue 7, pp. $20-27$. 
[15] Kadariya, S. (2012), Factors affecting investor decision making: A case of Nepalese capital market, Journal of Research in Economics and International Finance (JREIF), Vol. 1(1) pp. 16-30.

[16] Kahneman, D. and A. Tversky. (1973). Availability: A Heuristic for Judging Frequency and Probibality. Cognitive Psychology. 5(1)

[17] Kahneman, D. and A. Tversky (1979), Prospect Theory: Analysis of Decision under Risk; Econometrica, Vol. 47, pp. 263 $-292$.

[18] Mak, M. K., \& Ip, W. (2017). An exploratory study of investment behaviour of investors. International Journal of Engineering Business Management, 9, 184797901771152. doi:10.1177/1847979017711520.

[19] Manurung, A. H. (2019), Model dan Estimasi dalam Riset Manajemen dan Keuangan (Model and Estimation in Management dan Finance Research), PT Adler Manurung Press, Jakarta

[20] Mishra, K. C., \& Metilda, M. J. (2015). A study on the impact of investment experience, gender, and level of education on overconfidence and self-attribution bias. IIMB Management Review, 27(4), 228-239. doi: 10.1016/j.iimb.2015.09.001

[21] Nagy, R. A., \& Obenberger, R. W. (1994). Factors Influencing Individual Investor Behavior. Financial Analysts Journal, 50(4), 63-68. doi: 10.2469/faj.v50.n4.63

[22] Obamuyi, T. M. (2013), Factors Influencing Investment Decisions in Capital Market: A Study of Individual Investors in Nigeria, ORGANIZATIONS AND MARKETS IN EMERGING ECONOMIES, VOL. 4, No. 1, pp. 141 161.

[23] Olsen, R. A. (2008). Cognitive Dissonance: The Problem Facing Behavioral Finance. Journal of Behavioral Finance, 9(1), 1-4. doi:10.1080/15427560801896552

[24] Pahlevi, R. W. and I. I. Oktaviani (2018), Determinants of Individual Investor Behaviour in Stock Investment Decisions, Accounting and Financial Review, 1(2): p. 53-61,

[25] Phan, K. C. and J. Zhou (2014a), Factors Influencing Individual Investor Behavior: An Empirical Study of the Vietnamese Stock Market, American Journal of Business and Management, Vol. 3, No. 2, pp. 77-94.
[26] Phan, K. C. and J. Zhou (2014b), Vietnamnese Individual Investor Behavior in the Stock market: An Eexploratory Study, Research Journal of Social Science \& Management Vol. 3, No. 12, pp. 46 - 54.

[27] Phan, D.T.T., Le, V.H.T., \& Nguyen, T.T.H., (2020). Overconfidence Bias, Comparative Evidence between Vietnam, and Selected ASEAN Countries. Journal of Asian Finance, Economics and Business, Vol. 7, No. 3, 101-113. https://doi.org/10.13106/jafeb.2020.vol7.n o3.101

[28] Peranginangin, Y (2009), How the Indonesia Stock Exchange Reacts to Information: A Speed of Adjustment Coefficients Study, Indonesian Capital Market Review, Vol. 1, No. 2, pp 89-102.

[29] Riri, V., Manurung, A. H. and T. R. Kartika (2020); Effect of Overconfidence and Behavioral Motivation on Stock Investment Decisions; International Journal of Creative Research Thoughts, Vol. 8, Issue 11 ; pp. $503-510$.

[30] Rizvi and Abrar (2015), Factors Affecting an Individual Investor Behavior - An Empirical Study in Twin Cities (Rawalpindi and Islamabad) of Pakistan; International Journal of Economics and Management, Vol. 5, No. 5, pp. $1-27$.

[31] Sehgal, M. and D. Singh (2012). "Psychology of investors based on value and life-style survey." International Journal of Transformations in Business Management 2(2)

[32] Selden, G. C. (1912), The Psychology of The Stock Market, Ticker Publishing Company.

[33] Sharma, S., Durand, R. M. and O. Gur-Arie (1981), Identification and Analysis of Moderator Variables, Journal of Marketing, Vol. 18, No. 3, pp. $291-300$.

[34] Shiller, R. J. (2000). Measuring Bubble Expectations and Investor Confidence. Journal of Psychology and Financial Markets, Vol. 1, No. 1, pp, $49-60$. doi:10.1207/s15327760jpfm0101_05

[35] Slovic, P. (1972). Psycholgical Study of Human Judgment: Implications for Investment Decision Making; The Journal of Finance, 27(4), 779-799.

[36] Tekc, , B., and N. Yilmaz (2015). Are individual stock investors overconfident? Evidence from an emerging market. Journal 
of Behavioral and Experimental Finance, 5, 35-45.

[37] Wang, F. A (2001), Overconfidence, Investor Sentiment, and Evolution, Journal of Financial Intermediation, Vol. 10. pp. 138-170.

[38] Williams, G. (2007), Some Determinants of the Socially Responsible Investment Decision: A Cross-Country Study, The Journal of Behavioral Finance, Vol. 8, No. 1, pp. 43-57

[39] Xia, T., Wang, Z., \& Li, K. (2014). Financial Literacy Overconfidence and Stock Market Participation. Social Indicators Research, 119(3), 1233-1245.

[40] Zahera, S. A. and R. Bansal (2018), Do investors exhibit behavioral biases in investment decision making? A Systematic Review", Qualitative Research in Financial Markets, Vol. 10 Issue: 2, pp.210-251, https://doi.org/10.1108/QRFM-04-20170028Congress Marketing Trends, Venice, Italy.

[41] Huang, W.D., Yoo, S.J., \& Choi, J.H. (2008). Correlating college students' learning styles and how they use Web 2.0 applications for learning. In C. Bonk et al. (Eds.), Proceedings of World Conference on E-Learning in Corporate, Government, Healthcare, and Higher Education (pp. 2752-2759). Chesapeake, VA: AACE.

[42] Tingley, M. W., Monahan, W. B., Beissinger, S. R., \& Moritz, C. (2009). Birds track their Grinnellian nice through a century of climate change. Proceedings of the National Academy of Science, USA, 106,19637-19643.

[43] Govaerts, S., Verbert, K., Klerkx, J., \& Duval, E. (2010). Visualizing activities for self-reflection and awareness. Lecture Notes in Computer Science, 6483, 91-100.

[44] British Learning Association (2005). Quality mark profiles. Retrieved August 10. 2005, from http://www.britishlearning.org.uk/qualitymark/pages/profiles .htm

\section{Creative Commons Attribution License 4.0 (Attribution 4.0 International, CC BY 4.0)}

This article is published under the terms of the Creative Commons Attribution License 4.0

https://creativecommons.org/licenses/by/4.0/deed.en US 